\title{
RIGHT TO DEVELOPMENT AND EMOTIONAL EXHAUSTION: THE CASE OF HEALTHCARE INSTITUTIONS IN TURKEY
}

\author{
${ }^{1}$ Mehmet Emin Bilge, ${ }^{2}$ Rauf Karasu \& \\ ${ }^{3}$ Merve Aysegul Kulular Ibrahim \\ ${ }^{I}$ School of Law, Social Sciences University of Ankara, \\ Ankara, Turkey \\ ${ }^{2}$ School of Law, Hacettepe University, Ankara, Turkey \\ ${ }^{3}$ School of Law, Social Sciences University of Ankara, \\ Ankara, Turkey \\ Visiting Associate, Law Faculty, Murdoch University, \\ Perth, Australia
}

mehmetemin.bilge@asbu.edu.tr; raufkarasu@hacettepe.edu.tr; aysegul.kulular@asbu.edu.tr merve.

kulularibrahim@murdoch.edu.au

Received: 23/7/2019 Revised: 14/11/2019 Accepted: 17/11/2019 Published: 24/12/2019

\begin{abstract}
The right to development has a significant impact on a person. This right to development encompasses economic, social, cultural, and political development and it encourages individuals to participate actively in all four aspects of development. Although the scope is wide, with the individual, being the central subject of development, this study focuses on the right to development of healthcare professionals specifically on doctors and nurses. This study assessed the right to development of healthcare staff by considering their work conditions and other demographic characteristics. Significant fieldwork covering 20 healthcare institutions in three cities of Turkey was successfully conducted in the implementation of regulations regarding the right to development. This fieldwork used Maslach Burnout Inventory (MBI) for data collection. This article assessed the emotional exhaustion of 185 healthcare workers via SPSS program. The analysis found that educational status and type of healthcare institution had an effect on emotional exhaustion while other demographic characteristics such as work experience,
\end{abstract}


annual income or city of residence had no effect on the emotional exhaustion of healthcare professionals. In view of the results of this fieldwork, the correlation between emotional exhaustion and the right to development was discussed. The findings revealed that fear of aggression, lack of sufficient training, defamation or mobbing by senior doctors were potential adverse effects which caused emotional exhaustion among healthcare workers. To alleviate emotional exhaustion caused by work, institutions are advised to provide ongoing training or implement a sustainable method(s) for reducing patient burden and workload. Last but not least, as a sustainable solution, a nationwide precise legal monitoring mechanism covering both public and private, ordinary and university healthcare institutions is firmly recommended to be created for the prevention of infringement on the right to development of medical staff.

Keywords: Burnout, Emotional Exhaustion, Medical and Healthcare Law, Right to Development.

\section{INTRODUCTION}

Right to development is assessed under three different bases; on the basis of states, of energy sources and of human rights concerning developing countries. In fact, the right to development is and should be assessed as a right of each person to develop his/her character to participate and contribute socially, culturally and economically to society. This paper analyses the right to development in this respect. It aims to explore the significance of the right to development and analyses the impact of infringement on the right to development by way of medical professionals' burnout focusing on emotional exhaustion.

According to Maslach, the risk of burnout increases in human service institutions ${ }^{4}$ because working in face-to-face relationships with people tends to pose burnout. ${ }^{5}$ Due to the characteristics of their work, healthcare workers tend to have a high level of burnout.

4 Maslach, C., \& Jackson, S. E. (1981). The Measurement of Experienced Burnout. Journal of Occupational Behaviour, 2, p.99. - 113.

$5 \quad$ Nazik, F., Yilmaz, E., \& Tatli, H. (2018). Burnout in Health Sector: Sample of Public Hospital. Medicine Science, 7(4), p. 821. 
Burnout is defined as a state of fatigue ${ }^{6}$ by Freudenberger, who first introduced burnout in the literature. However, Maslach, whose burnout inventory was used in this work, defined burnout differently. According to his definition, burnout is a psychological syndrome. This syndrome consists of three categories: emotional exhaustion, depersonalization and reduced personal accomplishment. ${ }^{8}$

Emotional exhaustion includes feelings of being depleted, fatigued, or overextended. ${ }^{9}$ Emotional exhaustion, which is reduced energy levels or extreme fatigue, is claimed as the main symptom of burnout. ${ }^{10}$ As emotional exhaustion is the central component there are many researches which focused on emotional exhaustion ${ }^{11}$. These studies revealed the experience of $\operatorname{strain}^{12}$. Therefore this paper has also constrained analysis to the emotional exhaustion dimension of the Maslach Burnout Inventory, which is the most widely used research tool of job burnout. ${ }^{13}$

Even though many researches discussed patients' rights and many argued on nurses or doctors' burnout, there is no research which applied the methodology from quantitative research to qualitative research which considered emotional exhaustion which is the main part of burnout, as well as taking the right to development into account. The literature either focused on mere burnout or only on the right to development. However, this paper takes into account the correlation between emotional exhaustion and the right to development.

Freudenberger, H. (1974). Staff Burnout. Journal of Social Issues, 30, 159 - 165.

Maslach, C. (1982). Burnout: The Cost of Caring. Englewood Cliffs, NJ: Prentice Hall.

Maslach, C., Jackson, S. E., \& Leiter, M. (1996). Maslach Burnout Inventory Manual (3rd ed.). Palo Alto, CA: Consulting Psychologists Press.

9 Morse, G., Salyers, M. P., Rollins, A. L., Monroe-DeVita, M., \& Pfahler, C. (2012). Burnout in Mental Health Services: A Review of the Problem and Its Remediation. Administration and Policy in Mental Health and Mental Health Services Research, 39(5). p.341.

10 Duli, S. (2016). Years of Work Experience, an Important Predictor of Burnout in Special Education. American Scientific Research Journal for Engineering, Technology, and Sciences (ASRJETS), 17(1). p.318 (Sadati, et al., 2017, p. 368)

11 Halbesleben, J. R., \& Bowler, W. (2007). Emotional Exhaustion and Job Performance: The Mediating Role of Motivation. Journal of Applied Psychology, 92(1),p.93, 94.

12 Portoghese, I., Galletta, M., Burdorf, A., Cocco, P., D’Aloja, E., \& Campagna, M. (2017). Role Stress and Emotional Exhaustion Among Health Care Workers: The Buffering Effect of Supportive Coworker Climate in a Multilevel Perspective. Journal of Occupational and Environmental Medicine, 59(10), p.187.

13 Doulougeri, K., Georganta, K., \& Montgomery, A. (2016). "Diagnosing” Burnout among Healthcare Professionals: Can We Find Consensus? (L. Albert, Ed.) Cogent Medicine, 3(1). p.2. 
This study aims to explore whether there is a significant difference between different groups of healthcare professionals (limited to nurses and doctors) with regard to their marital status, gender, educational status, occupation, type of healthcare institution, age, work experience, annual income, and city of residence. The target of this work is to identify demographic variables and working conditions, which differ significantly between healthcare staff from different categories.

This study is organized as follows; after providing a brief explanation on research methodology, first it analyses significant differences and discusses findings from SPSS analysis. Next, it defines the right to development as an impact on the emotional exhaustion of different groups of healthcare professionals. Lastly, it discusses different factors affecting the right to development of healthcare staff, taking into account interviews with randomly chosen voluntary healthcare staff. To conclude, in targeting to decrease occupational burnout, this paper aims to propose an adequate and sustainable solution for the protection of personal rights, focusing on the right to development of medical professionals.

\section{METHODOLOGY}

\section{Sample}

In this study, a total of 22 questions were administered and the responses were measured by using a five-point Likert scale $(1=$ never, $5=$ always). The research took place in three cities in Turkey, namely Istanbul, Ankara, and Konya. A total of 185 participants from public and private healthcare institutions, including university related healthcare institutions comprising public and private universities participated in the study. The sample consisted predominantly of women ${ }^{14}$. It is a common feature of the healthcare sector in Turkey where more women than men are involved in

\footnotetext{
Even though there is a fact that society still has a perception claiming women are not suitable for corporate culture (Koyuncu, M., Burke, R. J., Alayoglu, N., \& Wolpin, J. (2014). Mentoring Relationships among Managerial and Professional Women in Turkey, Potential Benefits? Cross Cultural Management, 21(1), p.3), in fact like health care sector there are many types of sectors that women fill the needs of the institutions.
} 
nursing which is a female dominated occupation ${ }^{15}$. The majority of the respondents were aged 26 to 30 while $25.4 \%$ were aged 35 to 50 ; $14.1 \%$ were aged 31 to $35 ; 24.9 \%$ were aged 25 or lower and only $3.8 \%$ of the respondents were aged 51 or older. This work revealed that the majority of the respondents were young medical staff; who participated voluntarily and that they contributed more actively to the scientific questionnaires as compared to the older staff.

In terms of gender of the respondents, $75 \%$ were female medical staff and $25 \%$ were male medical staff. Respondents with more than 8 years of work experience accounted for the largest number that is, $35 \%$ of the total, followed by healthcare staff with 1 to 3 years of work experience $(31 \%)$. While those with 4 to 7 years of work experience took third place $(22 \%)$ and staff with less than a year of work experience formed the smallest number (10\%).

The statistical parcel of SPSS 23 was used to perform the calculations. Two statistical tests were applied to analyse the data. T-test was used to compare the means in two groups, and ANOVA to compare the means in multiple groups. ANOVA was preferred in order to make use of Tukey's test to determine the real differences between different categories in order to assess emotional exhaustion in the study. The level of statistical significance was fixed as equal or smaller than 0,05 .

This work analysed emotional exhaustion which has been argued as the main symptom of burnout, ${ }^{16}$ according to different categories, such as type of healthcare institution, educational level of medical staff, and age. Based on the analysis, the causes of emotional exhaustion and its relation to the right to development are discussed.

15 Evans, O., \& Steptoe, A. (2002). The Contribution of Gender-Role Orientation, Work Factors and Home Stressors to Psychological Wellbeing and Sickness Absence in Maleand Female-Dominated Occupational Groups. Social Science \& Medicine, 54, p.482.

16 Duli, 2016, p.318. 


\section{RESEARCH RESULTS}

\section{Reliability of Research}

Table 1: Reliability Statistics

\begin{tabular}{ll}
\hline Cronbach's Alpha & No. of Items \\
\hline .806 & 22 \\
\hline
\end{tabular}

The responses from staff were assessed for internal consistency. Table 1 shows the reliability statistics which indicate that the reliability of this research is high as the value of its Cronbach's Alpha is 0.806 .

\section{Descriptive Statistics}

This paper used independent-samples t-test analysis to explore whether there was a significant difference between the marital status of nurses and doctors or whether the difference stems from gender. While one-way ANOVA was used to measure significant differences for educational status according to emotional exhaustion of health care professionals. First, emotional exhaustion was mean-centred. Then, independent-samples t-test was applied for marital status and emotional exhaustion of nurses and doctors. The results are shown in Table 2.

According to Levene's test for equality of variances, the significance value is $0.829>0.05$ which means there is no statistically significant difference between the marital status of respondents and emotional exhaustion.

Next, independent samples t test was applied to find out whether there is a statistically significant difference between male and female healthcare workers. Some previous findings about burnout syndrome indicated that women who had more workload such as responsibilities in childcare, housework, ${ }^{17}$ or caring for older

17 Paoli, P., \& Merllié, D. (2001), Ten Years of Working Conditions in the European Union,. Luxembourg: Office for Official Publications of the European Communities, p.6. 
UUMJLS 10(2), July 2019 (157-182)
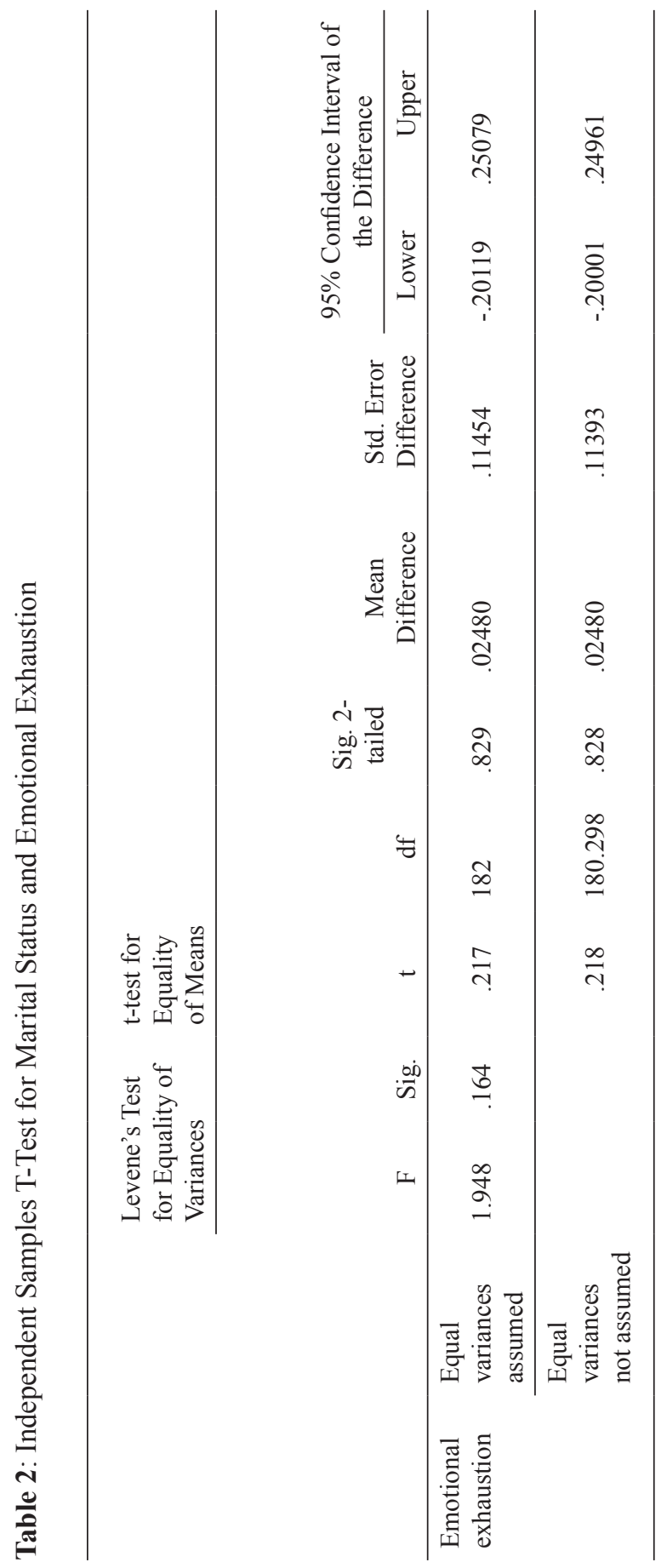
relatives ${ }^{18}$ were more frequently emotionally exhausted, ${ }^{19}$ while some other researches indicated the opposite. ${ }^{20}$ This research found no significant differences between gender groups as presented in Table 3 due to the significance value of 0.761 .

This means that even though women need additional sources of time not only for non-work demands such as caring for children, elderly relatives or to do housework, but also for their personal development in order to contribute socially, culturally, economically and/or social as they are thought to have more emotional characteristics than men. In this fieldwork the mean-centred emotional exhaustion of women did not differ significantly from the mean-centred emotional exhaustion of men. Some positive discrimination on women may be claimed as an impact. Since different studies on gender and burnout showed different results ${ }^{21}$, more detailed and long-term studies between different groups are encouraged to find out whether gender has a significant impact on burnout.

Table 3: Independent Samples T-Test for Gender and Emotional Exhaustion

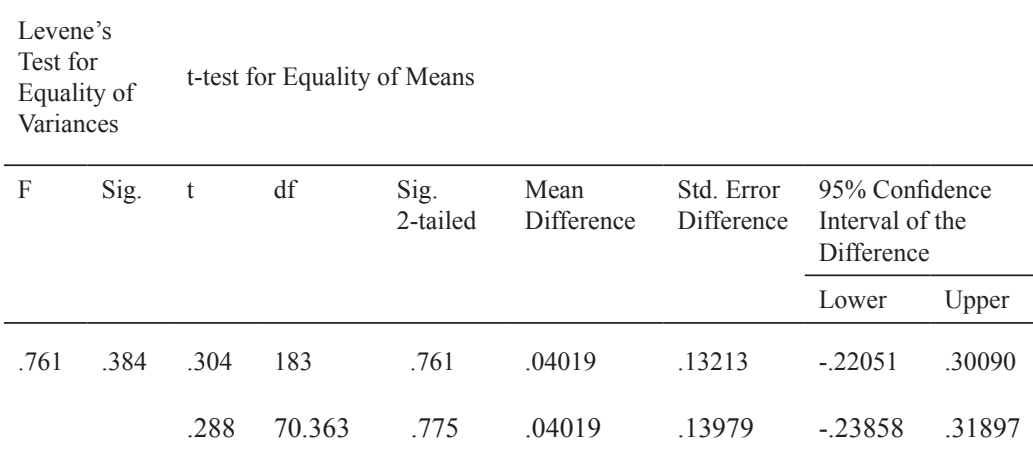

18 Bekker, M. H., Croon, M. A., \& Bressers, B. (2005), Childcare Involvement, Job Characteristics, Gender and Work Attitudes as Predictors of Emotional Exhaustion and Sickness Absence, Work and Stress, 19(3), p.222.

19 Bakker, A. B., Demerouti, E., \& Schaufeli, W. B. (2002), Validation of the Maslach Burnout Inventory - General Survey: An Internet Study, Anxiety, Stress, and Coping, 15(3), p.249.

20 Bekker, Croon, \& Bressers, 2005, p.229.

21 Bakker, Demerouti, \& Schaufeli, 2002, p.249. Bekker, Croon, \& Bressers, 2005, p.229. 
Emotional Exhaustion and Educational Status, Occupation, Age, Work Experience, Annual Income, Type of Healthcare Institution, and City of Residence

Table 4: ANOVA - Educational Status and Emotional Exhaustion

\begin{tabular}{lcrccc}
\hline & Sum of Squares & df & Mean Square & F & Sig. \\
\hline Between Groups & 5.271 & 3 & 1.757 & 3.023 & .031 \\
Within Groups & 105.213 & 181 & .581 & & \\
Total & 110.484 & 184 & & & \\
\hline
\end{tabular}

The hypothesis of whether there are significant differences between educational status and emotional exhaustion was analysed with ANOVA test. The results are shown in Table 4. The value of significance is $0.031<0.05$. This shows that there is a statistically significant difference between the educational status of healthcare staff and their emotional exhaustion.

Table 5: Test of Homogeneity of Variances

\begin{tabular}{cccc}
\hline Levene Statistic & df1 & df2 & Sig. \\
\hline .524 & 3 & 181 & .667 \\
\hline
\end{tabular}

Table 6: Multiple Comparisons

Dependent Variable: Emotional exhaustion_mean

Tukey HSD

\begin{tabular}{|c|c|c|c|c|c|c|}
\hline \multirow{2}{*}{$\begin{array}{l}\text { (I) } \\
\text { Educational } \\
\text { Status }\end{array}$} & \multirow{2}{*}{$\begin{array}{l}(\mathrm{J}) \\
\text { Educational } \\
\text { Status }\end{array}$} & \multirow{2}{*}{$\begin{array}{l}\text { Mean } \\
\text { Difference } \\
(\mathrm{I}-\mathrm{J})\end{array}$} & \multirow[t]{2}{*}{ Std. Error } & \multirow[t]{2}{*}{ Sig. } & \multicolumn{2}{|c|}{$\begin{array}{l}95 \% \text { Confidence } \\
\text { Interval }\end{array}$} \\
\hline & & & & & $\begin{array}{l}\text { Lower } \\
\text { Bound }\end{array}$ & $\begin{array}{l}\text { Upper } \\
\text { Bound }\end{array}$ \\
\hline \multirow[t]{3}{*}{ High School } & $\begin{array}{l}\text { Bachelor's } \\
\text { degree }\end{array}$ & $-.47804^{*}$ & .16819 & .026 & -.9142 & -.0419 \\
\hline & $\begin{array}{l}\text { Master's } \\
\text { degree }\end{array}$ & -.46878 & .19529 & .081 & -.9752 & .0376 \\
\hline & $\mathrm{PhD}$ & -.29127 & .19298 & .434 & -.7917 & .2091 \\
\hline
\end{tabular}


UUMJLS 10(2), July 2019 (157-182)

Dependent Variable: Emotional exhaustion_mean

Tukey HSD

\begin{tabular}{|c|c|c|c|c|c|c|}
\hline \multirow{2}{*}{$\begin{array}{l}\text { (I) } \\
\text { Educational } \\
\text { Status }\end{array}$} & \multirow{2}{*}{$\begin{array}{l}(\mathrm{J}) \\
\text { Educational } \\
\text { Status }\end{array}$} & \multirow{2}{*}{$\begin{array}{l}\text { Mean } \\
\text { Difference } \\
(\mathrm{I}-\mathrm{J})\end{array}$} & \multirow[t]{2}{*}{ Std. Error } & \multirow[t]{2}{*}{ Sig. } & \multicolumn{2}{|c|}{$\begin{array}{l}95 \% \text { Confidence } \\
\text { Interval }\end{array}$} \\
\hline & & & & & $\begin{array}{l}\text { Lower } \\
\text { Bound }\end{array}$ & $\begin{array}{l}\text { Upper } \\
\text { Bound }\end{array}$ \\
\hline \multirow{3}{*}{$\begin{array}{l}\text { Bachelor's } \\
\text { degree }\end{array}$} & High School & $.47804^{*}$ & .16819 & .026 & .0419 & .9142 \\
\hline & $\begin{array}{l}\text { Master's } \\
\text { degree }\end{array}$ & .00926 & .15286 & 1.000 & -.3871 & .4056 \\
\hline & $\mathrm{PhD}$ & 18677 & .14990 & .598 & -.2019 & .5755 \\
\hline \multirow{3}{*}{$\begin{array}{l}\text { Master's } \\
\text { degree }\end{array}$} & High School & .46878 & .19529 & .081 & -.0376 & .9752 \\
\hline & $\begin{array}{l}\text { Bachelor's } \\
\text { degree }\end{array}$ & -.00926 & .15286 & 1.000 & -.4056 & .3871 \\
\hline & $\mathrm{PhD}$ & .17751 & .17977 & .757 & -.2887 & .6437 \\
\hline \multirow[t]{3}{*}{$\mathrm{PhD}$} & High School & .29127 & .19298 & .434 & -.2091 & .7917 \\
\hline & $\begin{array}{l}\text { Bachelor's } \\
\text { degree }\end{array}$ & -.18677 & .14990 & .598 & -.5755 & .2019 \\
\hline & $\begin{array}{l}\text { Master's } \\
\text { degree }\end{array}$ & -.17751 & .17977 & .757 & -.6437 & .2887 \\
\hline
\end{tabular}

*. The mean difference is significant at the 0.05 level.

Before assessing Table 7, to have a reliable interpretation, it is necessary to check the results of Tukey's test for different educational status as shown in Table 6. According to Table 5, the significance value is $0.667>0.05$, therefore the variances are homogeneous which allows the authors to interpret Tukey's post hoc test.

According to Tukey's test (results from Table 6), there is no significant difference between the groups except for high school and university.

The only statistically significant difference is between university and high school due to a significance value of $0.026<0.05$. This result led the authors to relate emotional exhaustion of healthcare staff with their educational status: high school and university which is shown in Table 7.

Based on Table 7, the emotional exhaustion of healthcare staff who graduated from university is higher than those who graduated from 
Table 7: Descriptives

Emotional exhaustion and educational status

\begin{tabular}{|c|c|c|c|c|c|c|c|c|}
\hline & \multirow[b]{2}{*}{$\mathrm{N}$} & \multirow[b]{2}{*}{ Mean } & \multirow[b]{2}{*}{$\begin{array}{l}\text { Std. } \\
\text { Deviation }\end{array}$} & \multirow[b]{2}{*}{$\begin{array}{l}\text { Std. } \\
\text { Error }\end{array}$} & \multicolumn{2}{|c|}{$\begin{array}{l}\quad 95 \% \\
\text { Confidence } \\
\text { Interval for } \\
\text { Mean }\end{array}$} & \multirow[b]{2}{*}{ Min. } & \multirow[b]{2}{*}{ Max. } \\
\hline & & & & & $\begin{array}{l}\text { Lower } \\
\text { Bound }\end{array}$ & $\begin{array}{l}\text { Upper } \\
\text { Bound }\end{array}$ & & \\
\hline High school & 27 & 2.5205 & .83731 & .16114 & 2.1893 & 2.8517 & 1.25 & 4.38 \\
\hline $\begin{array}{l}\text { Bachelor's } \\
\text { degree }\end{array}$ & 86 & 2.9985 & .72874 & .07858 & 2.8423 & 3.1548 & 1.50 & 4.75 \\
\hline $\begin{array}{l}\text { Master's } \\
\text { degree }\end{array}$ & 35 & 2.9893 & .76238 & .12887 & 2.7274 & 3.2512 & 1.75 & 4.38 \\
\hline $\mathrm{PhD}$ & 37 & 2.8118 & .78321 & .12876 & 2.5506 & 3.0729 & 1.13 & 4.75 \\
\hline Total & 185 & 2.8897 & .77489 & .05697 & 2.7773 & 3.0021 & 1.13 & 4.75 \\
\hline
\end{tabular}

high school. In this study, healthcare staff is confined to nurses and doctors. Under Turkish law, a university degree is obligatory to become a doctor. However, for nurses, high school education is sufficient. As a result, the mean-centred emotional exhaustion of nurses with high school education is relatively lower than the mean-centred emotional exhaustion of doctors and nurses who have university degrees.

Table 8: Anova - Occupation (Doctors and Nurses) and Emotional Exhaustion

\begin{tabular}{crrrrr}
\hline & $\begin{array}{c}\text { Sum of } \\
\text { Squares }\end{array}$ & df & $\begin{array}{c}\text { Mean } \\
\text { Square }\end{array}$ & F & Sig. \\
\hline Between Groups & .075 & 1 & .075 & .125 & .724 \\
Within Groups & 110.409 & 183 & .603 & & \\
Total & 110.484 & 184 & & & \\
\hline
\end{tabular}

Analysis of the significant differences between occupation and emotional exhaustion can help clarify the significant differences between educational status and emotional exhaustion. For this analysis, the same criteria of assessment of the one-way ANOVA test on educational status and emotional exhaustion was applied. The results of the ANOVA test are presented in Table 8 which showed no significant differences between both groups (nurses and doctors). 
UUMJLS 10(2), July 2019 (157-182)

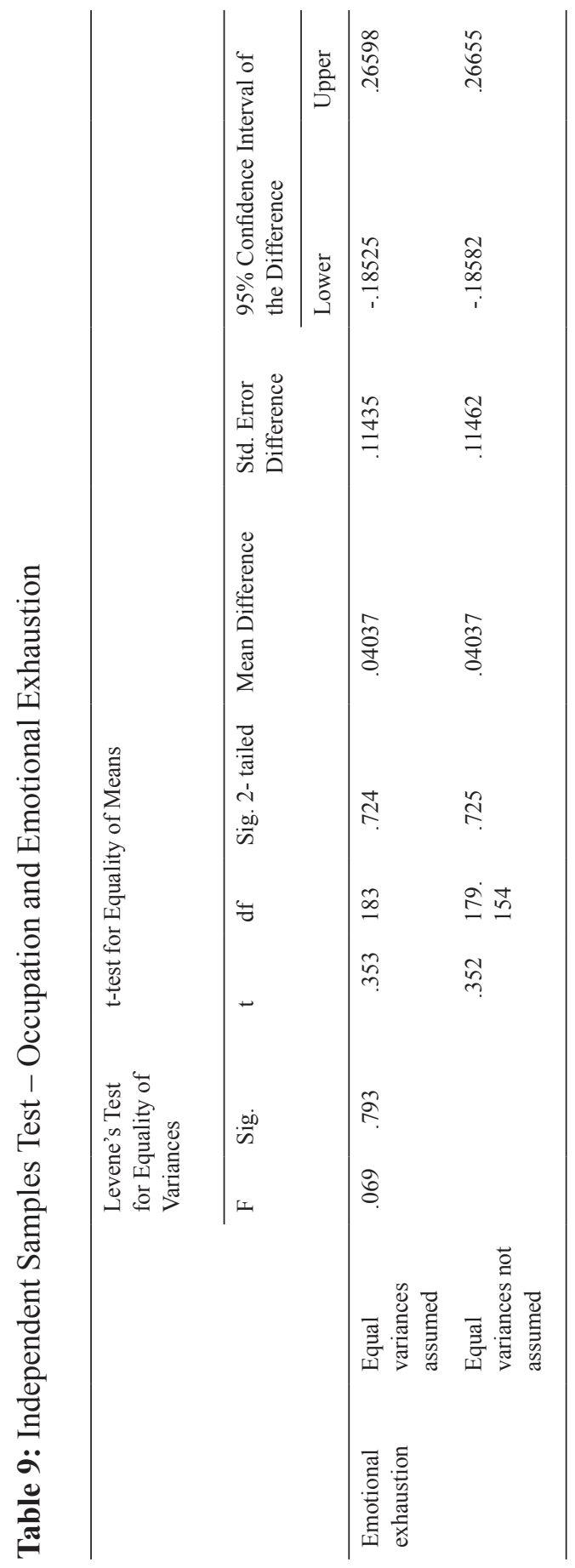


In addition, independent samples t-test was used to analyse significant differences between doctors or nurses. No significant differences were found between both groups as shown in Table 9. It clarifies that statistically, the educational status of medical staff is significantly different from emotional exhaustion. In other words, taking Table 8 into account, it can be argued that the emotional exhaustion of nurses with high school certificate education is relatively lower than the emotional exhaustion of doctors and nurses who have university and diploma education, respectively.

Another analysis illustrating significant differences between different types of healthcare institutions (public, private, public university, private university) is shown in Table 13, and the results of Anova in Table 10.

Table 10: Anova - Type of Healthcare Institution and Emotional Exhaustion Emotional Exhaustion_Mean

\begin{tabular}{ccccc}
\hline Sum of Squares & df & Mean Square & F & Sig. \\
\hline 14.494 & 3 & 4.831 & 9.110 & .000 \\
95.991 & 181 & .530 & & \\
110.484 & 184 & & & \\
\hline
\end{tabular}

Before interpreting Table 13, results of Tukey's test for different types of healthcare institutions shown in Table 12 should be assessed. From Table 11, the significance value is $0.514>0.05$, therefore the variances are homogeneous which allows the authors to interpret Tukey's post hoc test in Table 12.

Table 11: Test of Homogeneity of Variances Emotional Exhaustion Mean

\begin{tabular}{cccc}
\hline Levene Statistic & df1 & df2 & Sig. \\
\hline .767 & 3 & 181 & .514 \\
\hline
\end{tabular}


Table 12: Multiple Comparisons Dependent Variable: Emotional Exhaustion_Mean Tukey HSD

\begin{tabular}{|c|c|c|c|c|c|c|}
\hline \multirow[t]{3}{*}{ (I) Type } & \multirow[t]{3}{*}{ (J) Type } & \multirow{3}{*}{$\begin{array}{l}\text { Mean } \\
\text { Difference } \\
(\mathrm{I}-\mathrm{J})\end{array}$} & \multirow[t]{3}{*}{$\begin{array}{l}\text { Std. } \\
\text { Error }\end{array}$} & \multirow[t]{3}{*}{ Sig. } & \multicolumn{2}{|c|}{$\begin{array}{l}95 \% \text { Confidence } \\
\text { Interval }\end{array}$} \\
\hline & & & & & Lower & Upper \\
\hline & & & & & Bound & Bound \\
\hline \multirow[t]{3}{*}{ Private } & Public & $-.47607^{*}$ & .13570 & .003 & -.8279 & -.1242 \\
\hline & Private Uni & $-.92034^{*}$ & .18407 & .000 & -1.3976 & -.4430 \\
\hline & Public Uni & -.29633 & .16284 & .267 & -.7186 & .1259 \\
\hline \multirow[t]{3}{*}{ Public } & Private & $.47607^{*}$ & .13570 & .003 & .1242 & .8279 \\
\hline & Private Uni & $-.44427^{*}$ & .16949 & .046 & -.8838 & -.0048 \\
\hline & Public Uni & .17974 & .14615 & .609 & -.1992 & .5587 \\
\hline \multirow{3}{*}{$\begin{array}{l}\text { Private } \\
\text { University }\end{array}$} & Private & $.92034^{*}$ & .18407 & .000 & .4430 & 1.3976 \\
\hline & Public & $.44427^{*}$ & .16949 & .046 & .0048 & .8838 \\
\hline & Public Uni & $.62401^{*}$ & .19191 & .007 & .1264 & 1.1216 \\
\hline \multirow{3}{*}{$\begin{array}{l}\text { Public } \\
\text { University }\end{array}$} & Private & .29633 & .16284 & .267 & -.1259 & .7186 \\
\hline & Public & -.17974 & .14615 & .609 & -.5587 & .1992 \\
\hline & Private Uni & $-.62401^{*}$ & .19191 & .007 & -1.1216 & -.1264 \\
\hline
\end{tabular}

*. The mean difference is significant at the 0.05 level.

According to Table 12, there is a statistically significant difference between the emotional exhaustion of healthcare staff who worked in ordinary private hospitals, ordinary public hospitals, and in private university hospitals. However, no significant difference was found between healthcare staff working in ordinary public healthcare institutions or in ordinary private healthcare institutions and members working in public university hospitals. This result reveals that there is a significant difference between and among in the emotional exhaustion of healthcare professionals working in ordinary private hospitals, private university hospitals, and ordinary public hospitals. In addition, the emotional exhaustion of healthcare professionals in public and private university hospitals differed significantly.

Table 13 shows that the emotional exhaustion of healthcare professionals working in private university hospitals is higher than those working in ordinary public hospitals. Healthcare staff with 
Table 13: Descriptives Emotional Exhaustion_Mean

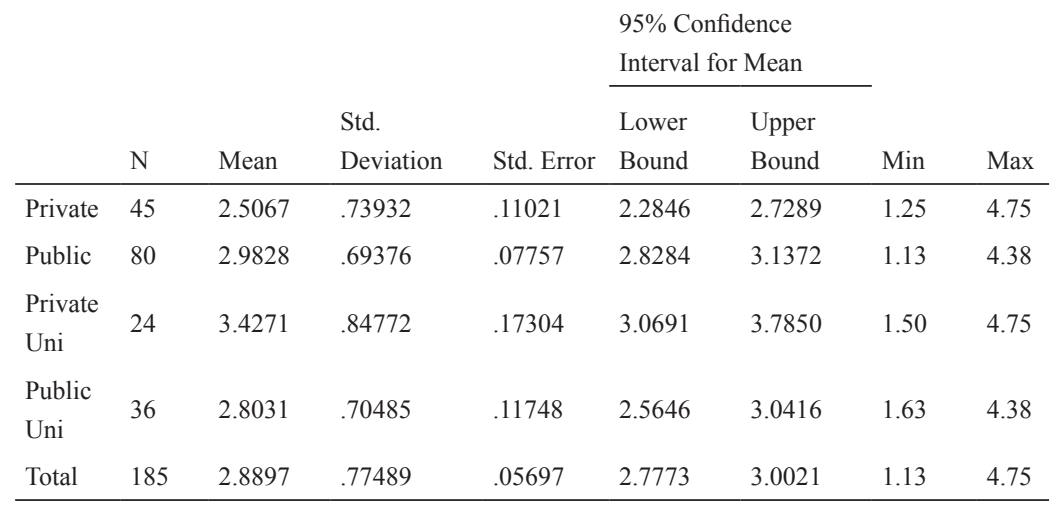

relatively low emotional exhaustion levels came from ordinary private hospitals or other types of ordinary private healthcare institutions.

On the other hand, there is a significant difference between emotional exhaustion and the type of university hospital healthcare staff. Table 13 shows that medical professionals working in private university hospitals have higher levels of emotional exhaustion in relation to those who work in public university hospitals.

Table 14: ANOVA - Age and Emotional Exhaustion Emotional Exhaustion_Mean

\begin{tabular}{lccccc}
\hline & $\begin{array}{c}\text { Sum of } \\
\text { Squares }\end{array}$ & df & $\begin{array}{c}\text { Mean } \\
\text { Square }\end{array}$ & F & Sig. \\
\hline Between Groups & 4.390 & 4 & 1.097 & 1.862 & .119 \\
Within Groups & 106.094 & 180 & .589 & & \\
Total & 110.484 & 184 & & & \\
\hline
\end{tabular}

In this research Anova test was applied to other categories such as age, work experience and annual income. However, no significant differences were found between the different categories. In the analysis of emotional exhaustion on different age groups, Table 
14 shows that there is no significant difference between young healthcare professionals, middle age or elderly healthcare staff.

Similar result was found in another Anova test which was applied based on the years of work experience and emotional exhaustion of healthcare professionals. Based on Table 15, there is no significant difference between healthcare professionals who had worked in the same position (doctor or nurse) for longer periods of time, as compared to healthcare staff who were new or just started working or had worked for shorter periods. Even though some researches explored using the main predictor of emotional exhaustion that is years of experience, ${ }^{22}$ in this research there was no significant difference in terms of work experience between the different groups.

Table 15: ANOVA - Work Experience and Emotional Exhaustion Emotional Exhaustion_Mean

\begin{tabular}{lccccc}
\hline & Sum of Squares & df & $\begin{array}{c}\text { Mean } \\
\text { Square }\end{array}$ & F & Sig. \\
\hline Between Groups & 1.627 & 3 & .542 & .903 & .441 \\
Within Groups & 108.113 & 180 & .601 & & \\
Total & 109.740 & 183 & & & \\
\hline
\end{tabular}

Table 16 shows that there is no significant difference in terms of annual income between the different groups.

Table 16: ANOVA - Annual Income and Emotional Exhaustion Emotional Exhaustion_Mean

\begin{tabular}{lrrrrr}
\hline & $\begin{array}{l}\text { Sum of } \\
\text { Squares }\end{array}$ & df & $\begin{array}{l}\text { Mean } \\
\text { Square }\end{array}$ & \multicolumn{1}{c}{ F } & \multicolumn{1}{c}{ Sig. } \\
\hline Between Groups & 2.131 & 4 & .533 & .881 & .477 \\
Within Groups & 107.660 & 178 & .605 & & \\
Total & 109.791 & 182 & & &
\end{tabular}

$\overline{22 \quad \text { Duli, 2016, p.320. }}$ 
Table 17: ANOVA - City of Residence and Emotional Exhaustion Emotional Exhaustion_Mean

\begin{tabular}{lcrccc}
\hline & Sum of Squares & \multicolumn{1}{c}{ df } & Mean Square & F & Sig. \\
\hline Between Groups & 2.556 & 2 & 1.278 & 2.155 & .119 \\
Within Groups & 107.929 & 182 & .593 & & \\
Total & 110.484 & 184 & & & \\
\hline
\end{tabular}

In another search to determine whether there is a significant difference between the emotional exhaustion of groups of healthcare professionals who resided in different cities, no significant difference was found as the significance value was 0.119 (Table 17). This revealed that even though residing in cosmopolitan cities like Istanbul or the capital city, Ankara has many disadvantages such as competition, traffic jam, high cost of living, and high patient load that could supposedly impact and increase emotional exhaustion, as compared to less populated cities like Konya, there was no significant difference in terms of emotional exhaustion between healthcare professionals living in Istanbul, Ankara, or Konya.

\section{DISCUSSION}

Based on the abovementioned analysis, there were significant differences between groups in terms of educational status and type of healthcare institution in this study. This study employed quantitative to qualitative research methods. Accordingly, voluntary healthcare professionals chosen at random, working in different types of healthcare institutions and having different educational levels were interviewed. The interview focused mainly on personal rights. Healthcare professionals interviewed emphasized on their right to development. As a result, this study analysed the right to development of healthcare professionals.

The UN General Assembly first adopted the right to development in 1986 as a resolution in the Declaration on the Right to Development. It defines right to development as "an inalienable human right by virtue of which every human person and all peoples are entitled to participate in, contribute to, and enjoy economic, social, cultural and 
political development, in which all human rights and fundamental freedoms can be fully realized. ${ }^{23}$ "

According to its historical background the right to development is based upon self-determination of states, in other words, equal sovereignty of states, considering sovereignty over resources, and equal participation for world affairs. ${ }^{24}$ However, in this paper, the right to development will be assessed as a part of personal rights based on its function allowing the beneficiary to participate and enjoy social, cultural and economic development. It has been argued that personal growth and development can result from dealing with burnout effectively. ${ }^{25}$ The emotional reality of the work of healthcare professionals has significant impact on their personal functioning. ${ }^{26}$ In view of these arguments, it can be claimed that burnout has a negative effect on personal development or infringes upon the right to personal development. Although both doctors and nurses being healthcare professionals are generally satisfied with their economic situation, there are significant issues to be discussed in terms of social and cultural development.

In view of the range in cultural and social backgrounds, the personalities and expectations of doctors and nurses are quite diverse. In spite of this, they share in common three main complaints relevant to burnout and their right to development.

First of all, patient burden of healthcare institutions is one of the main issues in Turkey. It causes long and tiring working hours and most of the time without lunch breaks. Most of the medical staff complained of not having enough sleep. Ordinary new healthcare staff who have just started working and aged 25 or lower, takes an average of 15000 steps, because new workers have heavy workload. Heavy workload have been argued as a source of burnout ${ }^{27}$. There are researches

\footnotetext{
United Nations Human Rights Office of the High Commissioner, (1986, December 4). Declaration on the Right to Development. Retrieved May 7, 2019, from https://www. ohchr.org/EN/ProfessionalInterest/Pages/RightToDevelopment.aspx

24 Kamga, S. D. (2018). Realizing the Right to Development: Some Reflections. History Compass, 16(7), e12460, p.3.

25 Burnout: From Tedium to Personal Growth, (1983), Children and Youth Services Review, 5(3), p.305.

26 Maslach C., Burnout in Health Professionals, 2007, p.427.

27 Maslach C. , Burnout in Health Professionals, 2007, p.428. Maslach \& Jackson, The Measurement of Experienced Burnout, 1981, p. 100.
} 
which reported that higher work overload increased emotional exhaustion $^{28}$. At the same time, it is a source of infringement upon the right to development since it limits the time for healthcare staff to participate in social and cultural development. In fact, states, and national or international institutions have obligations to make the right to development as an achievable human right ${ }^{29}$. Although healthcare institutions have this obligation to respect the right to development and make it achievable for their staff, there is no further step taken against heavy workload, which infringes upon the right to development. Moreover, healthcare institutions and even some healthcare professionals do not consider heavy workload as an infringing factor on the right to development.

Heavy workload does not only cause burnout and infringement of the right to development personally, it also causes social chaos. During the fieldwork, the authors encountered many discussions among doctors or nurses on patient burden. Some staff members mostly complained that they had more patient burden than others. The medical system in Turkey reserves the right to choose its hospital staff for patients. Accordingly, patients who made an effort in their search were able to choose competent doctors. This inevitably caused some doctors to have more patient burden than others. Even though their salaries increased according to their patient burden, doctors do not prefer to treat more patients in order to earn more. Instead, many doctors and nurses who were interviewed strongly emphasised that they would like to have more time to improve their knowledge and at least meet their basic needs since "sometimes they do not have time for lunch because of heavy workload." On the whole, the majority of the doctors complained about the same issue in the interviews.

Apart from heavy workload and patient burden, the second main complaint of the interviewees was about defamation and mobbing by not only patients but also by senior colleagues. In previous studies, egoistic individuals or authoritarianism were claimed to impact on burnout ${ }^{30}$. Defamation and mobbing caused healthcare staff to (Sadati, et al., 2017, p. 371)

29 Sengupta, A. (2002), On the Theory and Practice of the Right to Development, Human Rights Quarterly, 24(4), p.845.

30 Gann, M. L. (1979). The Role of Personality Factors and Job Characteristics in Burnout: A Study of Social Service Workers. Available from ProQuest Dissertations \& Theses Global: University of California, Berkeley. Retrieved 04 10, 2019, from http://libproxy. 
become more stressful. According to Poulin and Carolyn's research, a quarter of the variance for emotional exhaustion was job stress. ${ }^{31}$ However the relationship between emotional exhaustion and stress is not single-acting. The correlation is reciprocal. While stress has adverse impact on emotional exhaustion, emotional exhaustion also increases stress. This direct association between emotional exhaustion and stress was termed as "causal cycle" by Mayor. ${ }^{32}$

Defamation and mobbing also infringes on the right to development. Healthcare staff cannot participate in social and cultural activities at work due to fear of mobbing or defamation. A significant issue on the perception of mobbing or defamation was discovered during the interviews. Even though behaviour such as mobbing or defamation infringe on personal rights, the health care staff interviewed thought that such infringement was routine in medical work. It can be claimed as a result of common belief among service sector workers who argued that it was part of their job to have face-to-face encounters with people to dominate their emotions. ${ }^{33}$ This research reached the same conclusion as Ericson and Williams. They posited that many nurses thought that aggression was just a part of the job. ${ }^{34}$ As a result, they did not report aggression in healthcare institutions. Even though there is a centre for complaints in healthcare institutions, where patients can complain verbally or in written form, there is no such specific centre for healthcare professionals. Since the work environment normalises such behaviours, healthcare professionals with more work experience did not complain about defamation, or mobbing by colleagues. Having more work experience provided the medical staff with seniority. It can be said that older healthcare staff who are already seniors themselves, are not supposed to face defamation by other senior colleagues. However, young healthcare staff claimed that older healthcare professionals defamed a lot. This

murdoch.edu.au/login?url=https://search-proquest-com.libproxy.murdoch.edu.au/docvie w/302912885? accountid=12629. p.12, 13.

31 Poulin, J. E., \& Walter, C. A. (1993), Burnout in Gerontological Social Work, Social Work, 38(3), p.309.

32 Mayor, S. (2002, June 22). Emotional Exhaustion and Stress in Doctors are Linked. BMJ, $324(7352)$, p. 1475.

33 Hülsheger, U. R., Alberts, H. J., Feinholdt, A., \& Lang, J. W. (2013). Benefits of Mindfulness at Work: The Role of Mindfulness in Emotion Regulation, Emotional Exhaustion, and Job Satisfaction. Journal of Applied Psychology, 98(2), p. 311.

34 Erickson, L., \& Williams-Evans, S. A. (2000), Attitudes of Emergency Nurses Regarding Patient Assaults, Journal of Emergency Nursing, 26(3), p. 213. 
is also not only a barrier against the right to development but also against youth development. Youth development leads young people to build their character whilst contributing to and benefitting from society as part of their civic rights and duties ${ }^{35}$ while the right to development aims to prompt people of any age to build and develop their character.

Young healthcare professionals facing defamation consider it as part of their job. They also believe that defamation does not have a sufficient system in the healthcare institution. Even if they reported the aggression, those who assessed the reports were senior healthcare staff - they had already normalised aggression as part of the job. The fear of being insulted prevents new healthcare staff from raising issues relevant to patients or working with senior medical staff in their consultation. Consequently, the fear of aggression prevents healthcare staff from using their right to development.

The last issue that the majority of healthcare staff complained about was not having ongoing education and training support programs. In fact, it is obligatory for university hospitals to provide such programs, yet interviewees mentioned that most of the educational programs reported in reality did not exist. Since the opportunities for growth and development affected job satisfaction, ${ }^{36}$ failure to provide sufficient training could be another reason for the high mean in the emotional exhaustion of healthcare professionals working in university hospitals in comparison to ordinary hospitals as shown in Table 13.

The human-rights approach to development states that development assistance ought to create advantages in institutions. ${ }^{37}$ To respect the right to development, institutions should create opportunities for the participation of healthcare staff. The authors suggest providing

Yeon, A. L., Ayub, Z. A., Azhar, A., Abdullah, S. A., \& Arshad, R. (2016). View on Malaysian Law of Youth Development. UUM Journal of Legal Studies, 7, p. 75.

36 Kim, B., Liu, L., Ishikawa, H., \& Sang-Hee. (2019), Relationships between Social Support, Job Autonomy, Job Satisfaction, and Burnout among Care Workers in Longterm Care Facilities in Hawaii, Educational Gerontology, 45(1), p. 64.

37 Uvin, P. (2007), From the Right to Development to the Rightsbased Approach: How 'Human Rights' Entered Development, Development in Practice, 17(4-5), p. 603. Frankovits, A. (2001), Working Together: The Human Rights Based Approach to Development Cooperation, Stockholm Workshop 16-19 October 2000, Part 1: Report of the NGO Workshop 16-17 October, Sida. 
ongoing training or a sustainable method for reducing patient burden and workload could be considered as main opportunities for healthcare institutions. As a limitation of human rightsbased approach to development, lack of precise legal monitoring mechanisms ${ }^{38}$ can be claimed as another factor which has impact on emotional exhaustion. Lack of precise legal monitoring mechanisms is the reason why medical professionals considered that they must ignore infringements on their right to development by senior staff. To prevent infringement, a precise nation-wide legal monitoring mechanism should be developed.

\section{LIMITATIONS}

Even though this study has strong implications on healthcare professionals' emotional exhaustion and their right to development, there were some limitations. First, the research assessed the factors of work, instead it could also examine whether individual personal factors could alleviate burnout. Second, this study should be extended to include various components of other aspects such as cultural or family aspects since these factors may have implications on medical staff burnout and their right to development. This paper analysed emotional exhaustion, even though there are other dimensions of MBI, depersonalization, and personal accomplishment which could be explored in further investigations. Finally, this study had limitations in terms of generalization. It was conducted in only three cities in Turkey. Thus, a well-designed method using a large sample of healthcare institutions in Turkey could be considered in future studies.

\section{CONCLUSION}

Maslach posited that "the greater the gap between the person and the job, the greater the likelihood of burnout." ${ }^{39}$ Accordingly, it can be argued that infringement on the right to the development of

\footnotetext{
38 Frankovits, A. (2005), Introduction:A Rights-Based Approach to Development and the Right to Development, In M. Scheinin, \& M. Suksi (Eds.), Human Rights in Development Yearbook 2002 (pp. 3 - 15), Nordic Human Rights Publications.

39 Maslach C., Burnout in Health Professionals, 2007, p. 428.
} 
healthcare professionals due to heavy workload, mobbing, patient burden, defamation, lack of continuous education or training decreases job satisfaction and creates a gap between medical staff and their work. It is foreseeable that as long as the gap exists, the emotional exhaustion of medical staff will not decrease. Therefore, policymakers could come up with adequate solutions to eliminate or reduce this gap. Even though under international agreements or national regulations, health care professionals have the right to development and health care institutions have the obligation to provide satisfactory measures allowing for the right to development to be achievable for medical staff, this fieldwork found that implementation of these legislations were vague. To protect the right to development, a precise legal monitoring mechanism should be provided. This mechanism should be instituted by policymakers after taking into consideration different significant characteristics of healthcare institutions and professionals. Concurrently, existing regulations on medical law should be reviewed to ensure relevancy with the times and elements deemed missing could be explored, and accordingly current measures should come into force.

\section{ACKNOWLEDGEMENTS}

This study was funded by the Scientific Research Projects Commission of Social Sciences University of Ankara (SSUA). Project Code: SBA-2017-139.

\section{REFERENCES}

Bakker, A. B., Demerouti, E., \& Schaufeli, W. B. (2002). Validation of the Maslach Burnout Inventory - General survey: An internet study. Anxiety, Stress, and Coping, 15(3), 245-260.

Bekker, M. H., Croon, M. A., \& Bressers, B. (2005). Childcare involvement, job characteristics, gender and work attitudes as predictors of emotional exhaustion and sickness absence. Work and Stress, 19(3), 221-237.

Burnout: From tedium to personal growth. (1983). Children and Youth Services Review, 5(3), 305-307. 
Doulougeri, K., Georganta, K., \& Montgomery, A. (2016). "Diagnosing" burnout among healthcare professionals: Can we find consensus? (L. Albert, Ed.) Cogent Medicine, 3(1), $1-10$.

Duli, S. (2016). Years of work experience, an important predictor of burnout in special education. American Scientific Research Journal for Engineering, Technology, and Sciences (ASRJETS), 17(1), 318-322.

Erickson, L., \& Williams-Evans,, S. A. (2000). Attitudes of emergency nurses regarding patient assaults. Journal of Emergency Nursing, 26(3), 210-215.

Evans, O., \& Steptoe, A. (2002). The contribution of gender-role orientation, work factors and home stressors to psychological wellbeing and sickness absence in male- and femaledominated occupational groups. Social Science \& Medicine, $54,481-492$.

Frankovits, A. (2001). Working together: The Human rights based approach to development cooperation, Stockholm Workshop 16-19 October 2000. Part 1: Report of the NGO Workshop 16-17 October, Sida.

Frankovits, A. (2005). Introduction: A rights-based approach to development and the right to development. In M. Scheinin , \& M. Suksi (Eds.), Human Rights in Development Yearbook 2002 (pp. 3-15). Nordic Human Rights Publications.

Freudenberger, H. (1974). Staff Burnout. Journal of Social Issues, 30, 159-165.

Gann, M. L. (1979). The role of personality factors andjob characteristics in burnout: A study of social service workers. Available from ProQuest Dissertations \& Theses Global: University of California, Berkeley. Retrieved 04 10, 2019, from http://ibproxy.murdoch. edu.au/login?url=https://search-proquest-com.libproxy.murdoch. edu.au/docview/302912885?accountid=12629.

Halbesleben, J. R., \& Bowler, W. (2007). Emotional exhaustion and job performance: The mediating role of motivation. Journal of Applied Psychology, 92(1), 93-106.

Hülsheger, U. R., Alberts, H. J., Feinholdt, A., \& Lang, J. W. (2013). Benefits of mindfulness at work: The role of mindfulness in emotion regulation, emotional exhaustion, and job satisfaction. Journal of Applied Psychology, 98(2), 310-325. 
Kamga, S. D. (2018). Realizing the right to development: Some reflections. History Compass, 16(7), e12460.

Kim, B., Liu, L., Ishikawa, H., \& Sang-Hee. (2019). Relationships between social support, job autonomy, job satisfaction, and burnout among care workers in long-term care facilities in Hawaii. Educational Gerontology, 45(1).

Koyuncu, M., Burke, R. J., Alayoglu, N., \& Wolpin, J. (2014). Mentoring relationships among managerial and professional women in Turkey, Potential benefits? Cross Cultural Management, 21(1), 2-22.

Maslach, C. (1982). Burnout: The cost of caring. Englewood Cliffs, NJ: Prentice Hall.

Maslach, C. (2007). Burnout in health professionals. In S. Ayers, A. Baum, C. McManus, S. Newman, K. Wallston, J. Weinman, \& R. West (Eds.), Cambridge Handbook of Psychology, Health and Medicine (pp. 427-430). Cambridge University Press.

Maslach, C., Jackson, S. E., \& Leiter, M. (1996). Maslach burnout inventory manual (3rd ed.). Palo Alto, CA: Consulting Psychologists Press.

Maslach, C., \& Jackson, S. E. (1981). The measurement of experienced burnout. Journal of Occupational Behaviour, 2, 99-113.

Mayor, S. (2002, June 22). Emotional exhaustion and stress in doctors are linked. $B M J, 324(7352)$, p. 1475.

Morse, G., Salyers, M. P., Rollins, A. L., Monroe-DeVita, M., \& Pfahler, C. (2012). Burnout in mental health services: A review of the problem and its remediation. Administration and Policy in Mental Health and Mental Health Services Research, 39(5), 341-352.

Nazik, F., Yilmaz, E., \& Tatli, H. (2018). Burnout in health sector: Sample of public hospital. Medicine Science, 7(4), 821-825.

Paoli, P., \& Merllié, D. (2001). Ten years of working conditions in the European Union. Luxembourg: Office for Official Publications of the European Communities.

Portoghese, I., Galletta, M., Burdorf, A., Cocco, P., D’Aloja, E., \& Campagna, M. (2017). Role stress and emotional exhaustion among health care workers: The buffering effect of supportive coworker climate in a multilevel perspective. Journal of Occupational and Environmental Medicine, 59(10), 187-193. 
Poulin, J. E., \& Walter, C. A. (1993). Burnout in gerontological social work. Social Work, 38(3), 305-310.

Sadati, A. K., Rahnavard, F., Heydari, S. T., Hemmati, S., Ebrahimzadeh, N., \& Lankarani, K. B. (2017). Health sector reform, emotional exhaustion, and nursing burnout: A retrospective panel study in Iran. The Journal of Nursing Research, 25(5), 368-374.

Sengupta, A. (2002). On the theory and practice of the right to development. Human Rights Quarterly, 24(4), 837-889.

United Nations Human Rights Office of the High Commissioner. (1986, December 4). Declaration on the Right to Development. Retrieved from https:/www.ohchr.org/EN/ ProfessionalInterest/Pages/RightToDevelopment.aspx

Uvin, P. (2007). From the right to development to the rightsbased approach: How 'Human Rights' entered development. Development in Practice, 17(4-5), 597-606.

Yeon, A. L., Ayub, Z. A., Azhar, A., Abdullah, S. A., \& Arshad, R. (2016). View on Malaysian Law of youth development. UUM Journal of Legal Studies, 7, 71-82. 